\title{
GAME EDUKASI AKUNTANSI SEBAGAI SARANA PENINGKATAN MINAT BELAJAR SISWA (STUDI KASUS : SMK NEGERI 8 BANDAR LAMPUNG)
}

\author{
Yohana Tri Utami ${ }^{1)}$, Agatha Wahyu Septya Clara Yunita Putri ${ }^{2)}$ \\ 1) Ilmu Komputer, Universitas Lampung \\ ${ }^{2)}$ Sistem Informasi, Universitas Teknokrat Indonesia \\ 1)Jl. Prof. Dr. Ir. Sumantri Brojonegoro, No 1, Bandarlampung \\ ${ }^{21)}$ Jl. H.ZA Pagaralam, No 9-11, Labuhanratu,Bandarlampung \\ Email : yohana.utami@fmipa.unila.ac.id ${ }^{1)}$,agathawscyp12@gmail.com ${ }^{2}$
}

\begin{abstract}
Abstrak
Proses pembelajaran akuntansi syarat akan hitungan. Pokok bahasan ayat jurnal penyesuaian akuntansi merupakan pokok bahasan yang sangat sulit untuk di pahami siswa kelas $\mathrm{X}$ karena dalam pembelajaran tersebut terdapat unsur perhitungan yang abstrak dan tidak memiliki rumus seperti halnya pelajaran yang menggunakan perhitungan lainnya dan siswa merasa bosan pada pembelajaran secara konvensional. Tujuan penelitian ini adalah untuk merancang dan membangun aplikasi game edukasi sebagai sarana peningkatan minat belajar siswa.

Teknik pengumpulan data yang dilakukan pada penelitian ini yaitu menggunakan wawancara, kuisioner, dan tinjauan pustaka. Sumber data/subjek yaitu siswa SMK N 8 Bandar Lampung. Metode pengujian yang dilakukan yaitu terhadap aspek Usability, Functionality, Efficiency, dan Portability. Pengembangan aplikasi game edukasi akuntansi dibangun dengan menggunakan software Construct 2 yang akan dijalankan pada platform android.

Hasil pengujian kualitas aplikasi game di peroleh nilai dari aspek usability diperoleh $96 \%$, aspek functionality $99 \%$, aspek efficiency menunjukan tidak adanya kekurangan memory dan penggunaan CPU oleh aplikasi sebesar $47 \%$, dan aspek portability aplikasi hanya dapat di-instal dan dijalankan pada device dengan versi android Jelly Bean ke atas.
\end{abstract}

Kata kunci: Game, Akuntansi, Construct 2, Android.

\section{Pendahuluan}

\section{A. Latar Belakang Masalah}

Sekolah Menengah Kejuruan (SMK) merupakan jenjang pendidikan menengah yang mengutamakan pengembangan keterampilan peserta didik untuk melaksanakan jenis pekerjaan tertentu. Salah satu mata pelajaran yang dapat mengembangkan keterampilan adalah Akuntansi. Untuk dapat memahami mata pelajaran akuntansi secara luas maka harus dimulai dengan kemampuan kognitifnya yaitu pemahaman konsep dasar yang ada pada pelajaran akuntansi. Oleh karena itu, dalam proses pembelajaran akuntansi tersebut diperlukan pemahaman yang cukup. Pokok bahasan ayat jurnal penyesuaian akuntansi merupakan pokok bahasan yang sangat sulit untuk di pahami siswa karena dalam pembelajaran tersebut terdapat unsur perhitungan yang abstrak dan tidak memiliki rumus.

Dalam dunia pendidikan perkembangan Teknologi Informasi mulai memiliki dampak yang positif dan mulai memperlihatkan perubahan yang cukup signifikan. Game edukasi adalah salah satu contoh dari media pembelajaran menggunakan media game. Game edukasi menerapkan sistem pembelajaran langsung dengan pola Learning by doing. Pola pembelajaran yang dilakukan dengan cara bermain dapat melalui tantangan-tantangan yang ada dalam permainan game ataupun faktor kegagalan yang dialami sang pemain, sehingga pemain untuk tidak mengulangi kegagalan dalam tahap berikutnya.

Berdasarkan identifikasi masalah diatas, maka media pembelajaran ayat jurnal penyesuaian ditanamkan dan diimplementasikan dengan memanfaatkan trend teknologi dengan tujuan untuk meningkatkan daya tarik edukasi cara yang lebih praktis, solusi yang diusulkan dalam mengatasi masalah-masalah yang berkaitan dengan ayat jurnal penyesuaian yaitu membangun aplikasi game menggunakan Construct 2. Perancangan aplikasi game edukasi ini akan dirancang dengan pemodelan berorientasi objek (UML). Kelebihan dari aplikasi game ini adalah membantu siswa dalam belajar tetapi tidak merasa monoton dan menjenuhkan, maka penulis mengusulkan judul "Game Edukasi Akuntansi Sebagai Sarana Peningkatan Minat Belajar Siswa (Study Kasus : SMK Negeri 8 Bandar Lampung)" yang berbasis android sebagai media pembelajaran.

\section{B. Rumusan Masalah}

Dari latar belakang masalah yang telah diuraikan di atas, maka penulis merumuskan permasalahan pada penelitian ini yaitu:

1. Bagaimana cara mendesain game untuk meningkatkan minat belajar pada siswa SMK Negeri 8 Bandar Lampung?

2. Bagaimana membuat game edukasi yang diminati oleh siswa?

\section{Batasan Masalah}

Agar penelitian yang dilakukan dapat lebih terarah, maka perlu dilakukan pembatasan masalah yang akan dibahas, batasan masalah tersebut sebagai berikut:

1. Pembahasan dibatasi hanya seputar pembelajaran Ayat Jurnal Penyesuaian pada perusahaan jasa. 
2. Ditujukan untuk siswa SMK Negeri 8 Bandar Lampung kelas X (sepuluh).

3. Tampilan yang disajikan sangat sederhana dengan genre petualangan.

4. Tampilan antar muka dalam game edukasi ini adalah tampilan 2D.

\section{Tujuan}

Tujuan dari penelitian ini adalah sebagai berikut:

1. Untuk meningkatkan minat belajar pada siswa SMK Negeri 8 Bandar Lampung.

2. Untuk menghasilkan suatu produk berupa Game edukasi untuk siswa SMK Negeri 8 Bandar Lampung.

\section{E. Tinjauan Pustaka}

1. Mohamad Adiwijaya, Kodrat Iman S, dan Yuli Christyono, 2015 meneliti tentang Perancangan Game Edukasi Platform Belajar Matematika Berbasis Android Menggunakan Construct 2.

2. Hanny Haryanto dan Rahmatsyam Lakoro, 2012 meneliti tentang Game Edukasi "Evakuator" Bergenre Puzzle Dengan Gameplay Berbasis Klasifikasi Sebagai Sarana Pendidikan Dalam Mitigasi Bencana.

3. Nia Ayu Sriwahyuni dan Mardono, 2016 meneliti tentang Pengembangan Media Pembelajaran Game Edukasi Pada Mata Pelajaran Ekonomi Kelas X IIS SMA Laboratorium Universitas Negri Malang.

4. Ditto Rahmawan Putra dan Mahendra Adhi Nugroho, 2016 meneliti tentang Pengembangan Game Edukatif Berbasis Android Sebagai Media Pembelajaran Akuntansi Pada Materi Jurnal Penyesuaian Perusahaan Jasa.

5. Mariati., 2016 meneliti tentang Pengembangan Media Pembelajaran Multimedia Interaktif Model Games "Gedutan" Dalam Pembelajaran Akuntansi Pada Siswa Kelas X Smk - Bm Se- Kota Medan.

\section{F. Landasan Teori}

\section{1) Pengertian Sistem Informasi Akuntansi}

Sistem informasi akuntansi adalah suatu system yang megumpulkan, mencatat, menyimpan dan mengelola data untuk menghasilkan informasi bagi pengambil keputusan. Sistem ini meliputi orang, prosedur dan intruksi, data, perangkat lunak, infrastruktur teknologi informasi, serta pengendalian internal dan ukuran keamanan (Romney dan Steinbart, 2016)

\section{2) Pengertian Ayat Jurnal Penyesuaian (Perusahaan Jasa)}

Ayat jurnal penyesuaian adalah jurnal yang dibuat dalam proses pencatatan perubahan saldo dalam beberapa akun sehingga saldo mencerminkan jumlah saldo yang sebenarnya, untuk memisahkan antara biaya yang sudah menjadi beban pada suatu periode akuntansi dengan yang belum (Sucipto et al, 2011: 43)

\section{3) Media Pembelajaran}

Media pembelajaran adalah perantara atau pengantar informasi berupa pesan - pesan yang bertujuan instruksional atau mengandung maksud maksud pengajaran yang memungkinkan terjadinya komunikasi dari pengirim menuju penerima (Azhar Arsyad, 2011).

Media pembelajaran adalah segala sesuatu yang dapat menyampaikan dan menyalurkan pesan dari sumber terencana sehingga tercipta lingkungan belajar yang kondusif dan proses secara efisien dan efektif (Munadi 2008).

Dari kedua uraian diatas, penulis menyimpulkan bahwa Media pembelajaran adalah alat yang berfungsi untuk menyampaikan pesan pada proses pembelajaran.

\section{4) Game Edukasi}

Game edukasi adalah permainan yang disertai pembelajaran dan merupakan media pembelajaran terbaru yang diharapkan dapat meningkatkan pemahaman dengan cepat karena didukung permainan yang menarik dan membuat siswa menjadi aktif dan proses interaksi peserta didik dengan pendidik dan sumber belajar pada suatu lingkungan belajar Dony Novaliendry (2013).

\section{G. Metode Pengembangan Mutimedia MDLC}

Multimedia Development Life Cycle menurut Luther dalam Sutopo (2003) pengembangan sistem multimedia dilakukan berdasarkan enam tahap yaitu: concept, design, material collecting, assembly, testing, distribution.

\section{H. ISO 9126}

Salah satu tolak ukur kualitas perangkat lunak adalah ISO 9126, yang dibuat oleh International Organization for Standardization (ISO) dan International Electrotechnical Commission (IEC). ISO 9126 mendefinisikan kualitas produk perangkat lunak, model, karakteristik mutu, dan metrik terkait yang digunakan untuk mengevaluasi dan menetapkan kualitas sebuah produk software. Faktor kualitas menurut ISO 9126 meliputi enam karakteristik kualitas sebagai berikut:(AlQutaish 2010)

1) Functionality (Fungsionalitas).

2) Reliability (Kehandalan).

3) Usability (Kebergunaan).

4) Efficiency (Efisiensi).

5) Maintainability (Pemeliharaan).

6) Portability (Portabilitas).

\section{Pembahasan}

\section{A. Perancangan Game}

Dalam perancangan game ini memiliki tahap - tahap yang akan dilakukan dengan menggunakan metode pengembangan multimedia menurut Luther- Sutopo yang terdiri dari enam tahap, yaitu Concept (Pengonsepan), Design (Perancangan), Material Collecting (Pengumpulan Bahan), Assembly (Pembuatan), Testing (Pengujian), Distribution (Penyebaran). 


\section{1) Concept (Pengonsepan)}

Pada penelitian ini akan dikembangkan sebuah game dengan konsep game edukasi menggunakan platform Android dengan tampilan dua dimensi (2D). Game Pengenalan dasar - dasar akuntansi ini termasuk dalam genre edugames karena game ini di spesifikasikan pada unsure pendidikan yang memuat nilai-nilai pembelajaran materi sebagai sarana hiburan yang bersifat mendidik, serta sebagai alternative meningkatkan dan memperluas pengetahuan pemain dalam mengenal materi dasar dasar akuntansi.

\section{2) Design (Perancangan)}

Tahap ini merupakan tahap perancangan arsitektur program, gaya, tampilan, dan kebutuhan material atau bahan untuk program. Tahap perancangan yang dibuat meliputi menentukan gameplay, perancangan flowchart game, dan storyboard.

\section{a. Game Play}

Gameplay merupakan tingkat dan sifat interaktifitas pemain dimana pemain dapat berinteraksi dengan dunia game dan game tersebut dapat menerima reaksi yang dipilih pemain. Gameplay dapat dilihat pada tabel 1 dibawah ini:

Tabel 1. Game Play

\begin{tabular}{|c|l|}
\hline No & \multicolumn{1}{|c|}{ Aksi } \\
\hline 1 & Menampilkan halaman intro. \\
\hline 2 & Menampilkan halaman awal game. \\
\hline 3 & $\begin{array}{l}\text { Pemain memilih kategori game yang ingin } \\
\text { dimainkan. }\end{array}$ \\
\hline 4 & Pemain memilih level permainan. \\
\hline 5 & Permainan ditampilkan. \\
\hline 6 & $\begin{array}{l}\text { Pemain memilih jawaban pada kolom } \\
\text { jawaban. }\end{array}$ \\
\hline 7 & $\begin{array}{l}\text { Menampilkan soal selanjutnya. } \\
\text { sebagai point score yang di dapat. }\end{array}$ \\
\hline 8 & $\begin{array}{l}\text { Jika jawaban salah akan muncul tulisan "0" } \\
\text { sebagai poin score yang tidak di dapat. }\end{array}$ \\
\hline 10 & $\begin{array}{l}\text { Menampilkan Score jika benar maka } \\
\text { mendapatkan nilai }+ \text { dan jika salah nilai } \\
\text { tetap. }\end{array}$ \\
\hline 11 & $\begin{array}{l}\text { Pemain dapat memilih atau kembali ke menu } \\
\text { pilih game. }\end{array}$ \\
\hline 12 & $\begin{array}{l}\text { Pemain memilih menu materi untuk belajar } \\
\text { Ayat Jurnal Penyesuaian. }\end{array}$ \\
\hline 13 & $\begin{array}{l}\text { Pemain memilih menu tentang untuk } \\
\text { mengetahui informasi pembuat aplikasi. }\end{array}$ \\
\hline 14 & $\begin{array}{l}\text { Pemain memilih petunjuk untuk mengetahui } \\
\text { informasi memainkan karakter game. }\end{array}$ \\
\hline
\end{tabular}

\section{b) Flowchart Game}

Dalam aplikasi game pengenalan dasar - dasar akuntansi ini flowchart digunakan untuk menggambarkan alur aplikasi game. Flowchart game dapat dilihat pada gambar 2 dibawah ini:

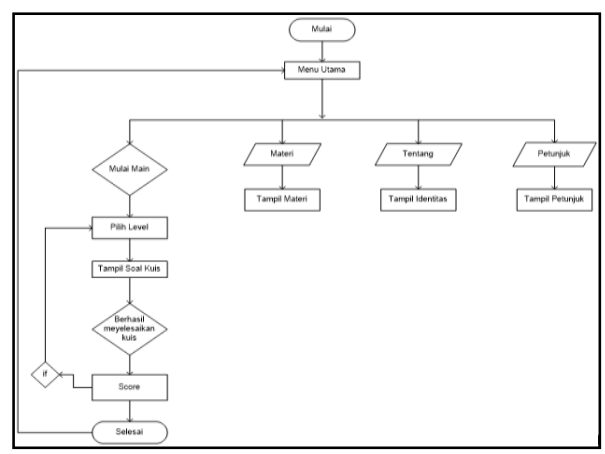

Gambar 2 Diagram Alir (Flowchart) Aplikasi Game

\section{c) Story Board Game}

Story Board Game ini merupakan rancangan interface atau antarmuka dari aplikasi game yang dilengkapi spesifikasi dari setiap gambar, layer dan teks. Rancangan Storyboard dapat dilihat pada Tabel 2 dibawah ini:

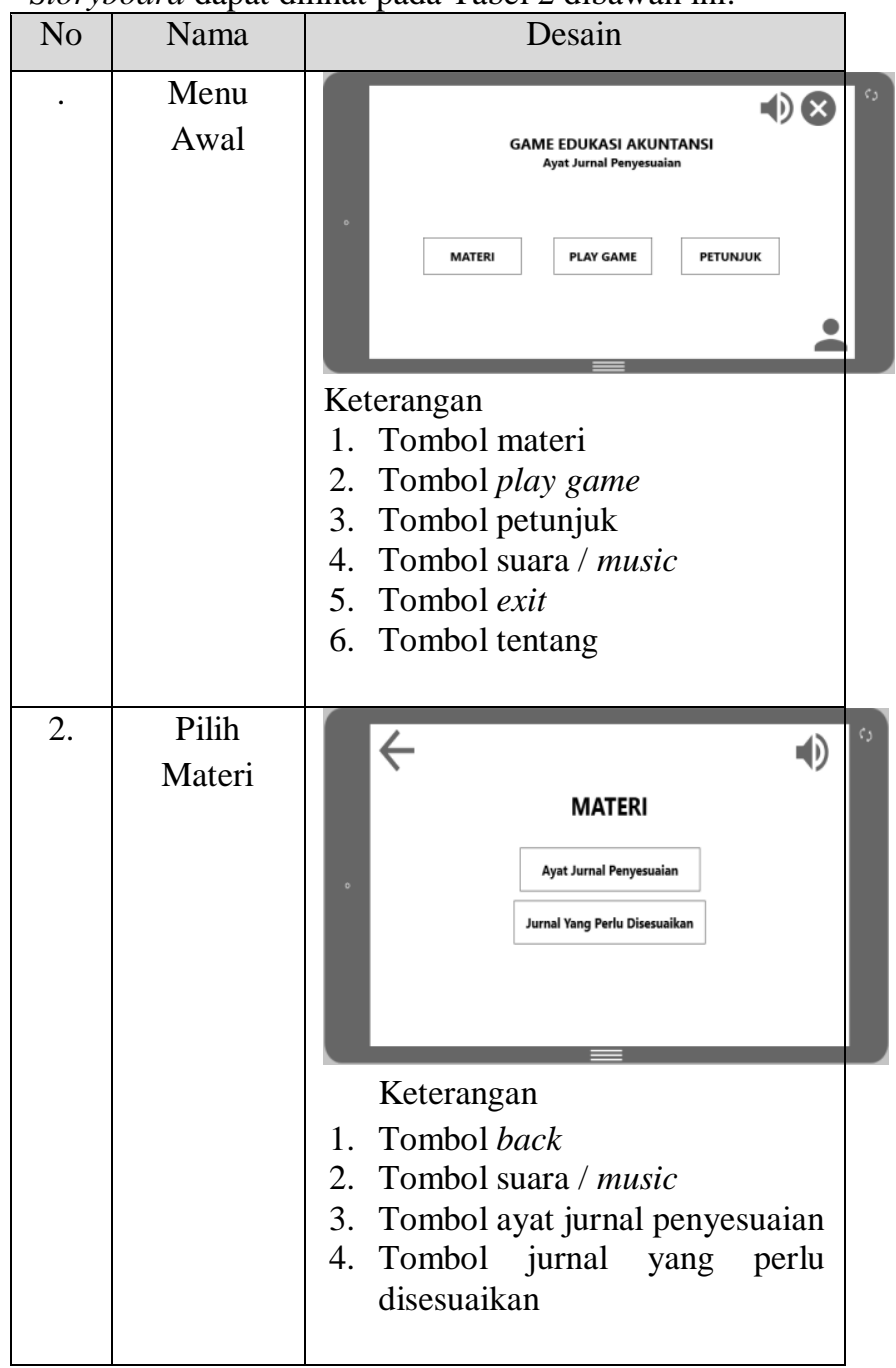




\begin{tabular}{|c|c|c|}
\hline 3. & $\begin{array}{c}\text { Tampilan } \\
\text { Materi }\end{array}$ & $\begin{array}{l}\leftarrow \text { Ayat Jurnal Penyesuaian } \\
\text { Keterangan } \\
\text { 1. Tombol back } \\
\text { 2. Tombol suara / music } \\
\text { 3. Isi materi dapat di scroll }\end{array}$ \\
\hline 4. & $\begin{array}{l}\text { Pilih } \\
\text { Play } \\
\text { Game }\end{array}$ & $\begin{array}{l}\text { Keterangan } \\
\text { 1. Tombol back } \\
\text { 2. Tombol suara / music } \\
\text { 3. Tombol Level yang dipilih } \\
\text { (Permainan harus menyelesaikan } \\
\text { lever awal untuk melanjutkan } \\
\text { level selanjutnya) }\end{array}$ \\
\hline 5. & $\begin{array}{l}\text { Tampila } \\
\text { n Game }\end{array}$ & $\begin{array}{l}\text { Keterangan } \\
\text { 1. Tombol home untuk kembali ke } \\
\text { menu utama } \\
\text { 2. Tombol suara / music } \\
\text { 3. Tampilan nyawa karakter } \\
\text { 4. Tampilan point } \\
\text { 5. Tampilan nilai sementara setelah } \\
\text { menjawab soal } \\
\text { 6. Tombol untuk } \\
\text { kekiri/kekanan bergergak } \\
\text { 7. Tombol untuk loncat } \\
\text { 8. Tombol untuk lari cepat }\end{array}$ \\
\hline
\end{tabular}

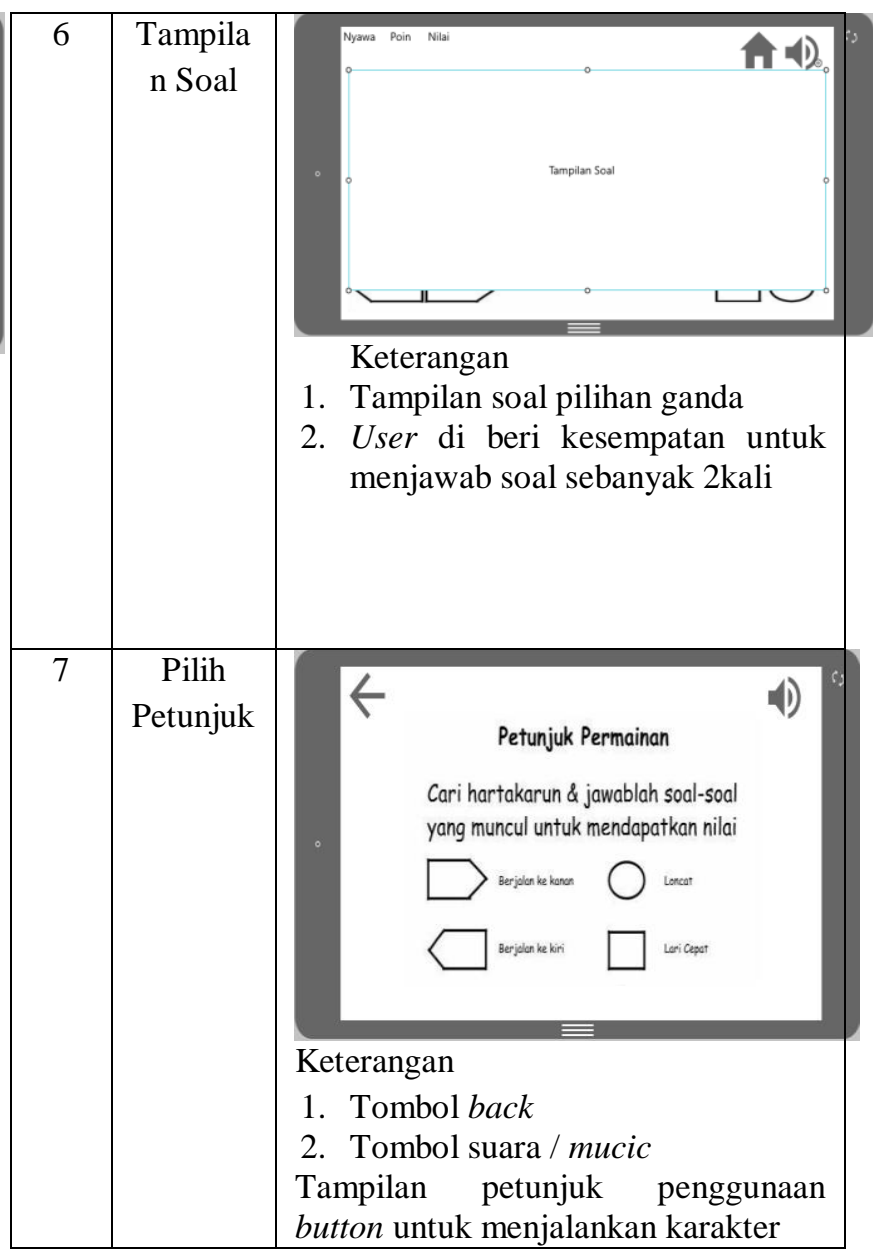

\section{Desain Sistem}

Berikut gambaran perancangan sistem yang diusulkan menggunakan $U M L$ :

a. Use Case Diagram

Diagram Use Case menunjukan interaksi system dengan pengguna dalam model grafik. Berikut ini gambaran aktivitas kegiatan penggunaan system tersebut pada gambar 3 dibawah ini :

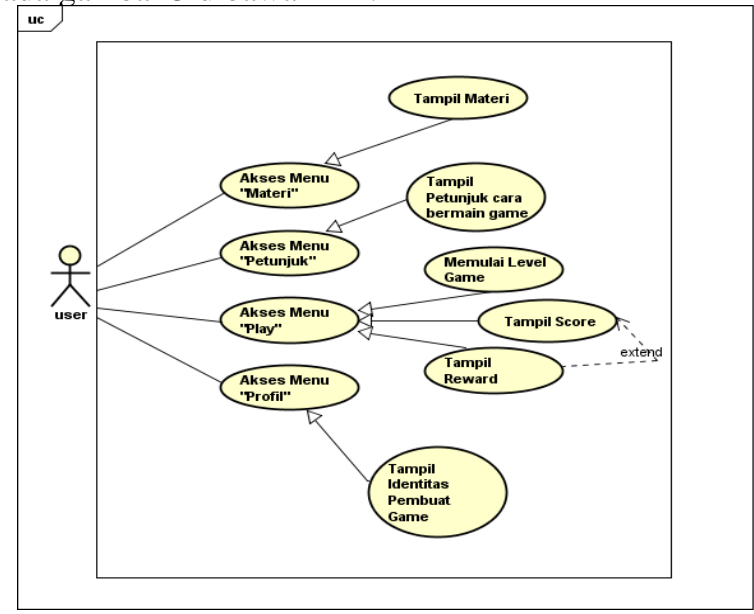

\section{Gambar 3. Use Case Diagram}

\section{3) Material Collecting}

Pada tahap ini dilakukan pengumpulan materi atau bahan berupa materi dasar - dasar akuntansi, gambar gambar jurnal, gambar - gambar background dan lain lain. 


\section{4) Assembly (Pembuatan)}

Tahap ini merupakan tahap pembuatan dari semua bahan - bahan yang telah terkumpul dan berdasarkan pada tahap design yaitu flowchart game dan storyboard game kemudian diimplementasikan menjadi sebuah game edukasi. Pada tahap pembuatan pada game ini menggunakan game engine Construct 2 berbasis HTML 5 yang di produksi oleh scirra.

\section{5) Testing (Pengujian)}

Pada tahap ini pengujian dilakukan dengan menggunakan standar kualitas ISO 9126. Penelitian ini hanya 4 aspek saja. Berikut ini daftar yang digunakan dalam penelitian:

\section{Aspek Functionality}

Untuk pengujian aspek functionality menggunakan kuesioner yang berisi daftar fungsi yang dimiliki aplikasi. Kuisioner diisi oleh orang yang memiliki keahlian dalam bidang software engineering.

\section{Aspek Usability}

Untuk pengujian aspek usability pada penelitian ini menggunakan kuisioner yang diisi oleh siswa SMK Negeri 8 Bandar Lampung.

\section{Aspek Portability}

Untuk pengujian aspek portability menggunakan perangkat dengan OS Android versi Gingerbread, Jelly Bean, Kitkat, Lollipop, Marshmallow dan Nougat.

\section{Aspek Efficiency}

Untuk pengujian aspek efficiency menggunakan Testdroid yang dapat diakses di https://cloud.testdroid.com. Dengan Testdroid dapat menganalisis waktu yang dibutuhkan untuk memberikan respon saat menjalankan suatu fungsi dan kapabilitas software untuk memelihara tingkat performa.

\section{B) Implementasi Interface}

Tahap implementasi merupakan tahap translasi desain yang telah dirancang ke dalam kode program, implementasi yang dilakukan meliputi implementasi rancangan antar muka (user interface). Sesuai dengan rancangan storyboard yang sudah dibuat, maka hasil implementasi rancangan interface adalah sebagai berikut:

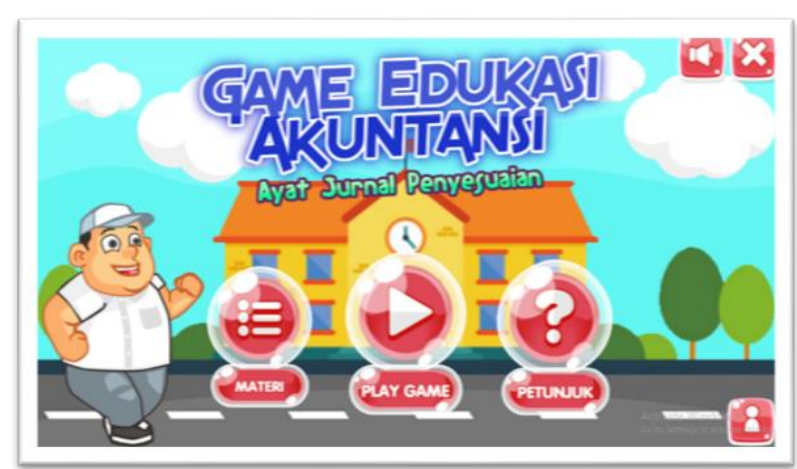

Gambar 4. Tampilan Menu Utama

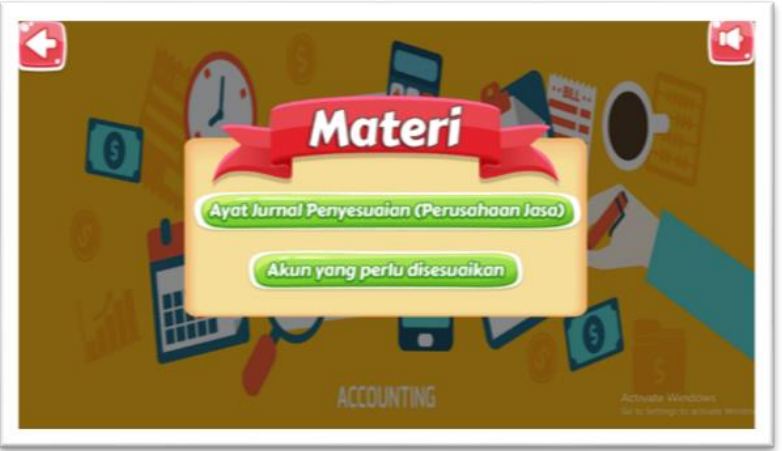

Gambar 5. Tampilan Menu Materi

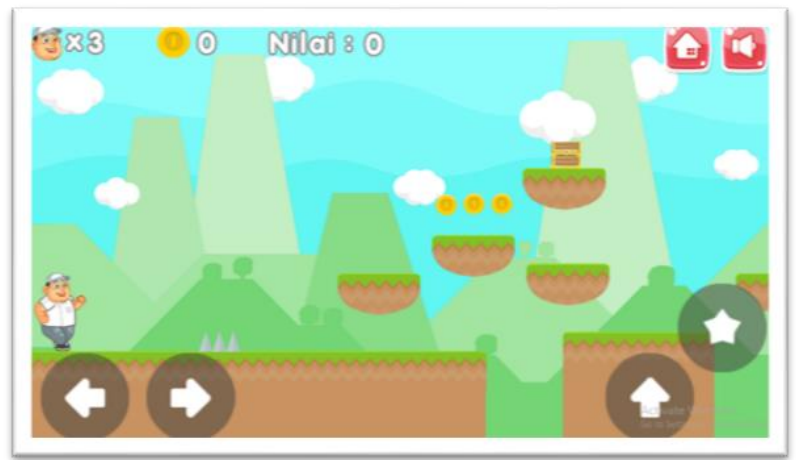

Gambar 6. Tampilan Game

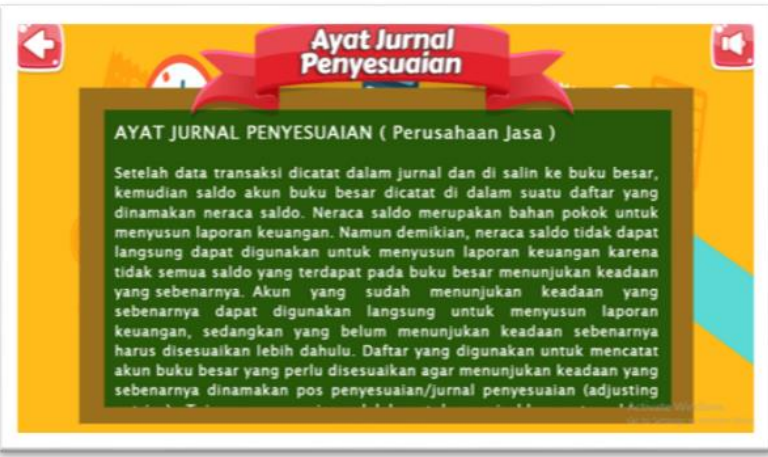

Gambar 7. Tampilan Materi Ayat Jurnal Penyesuaian

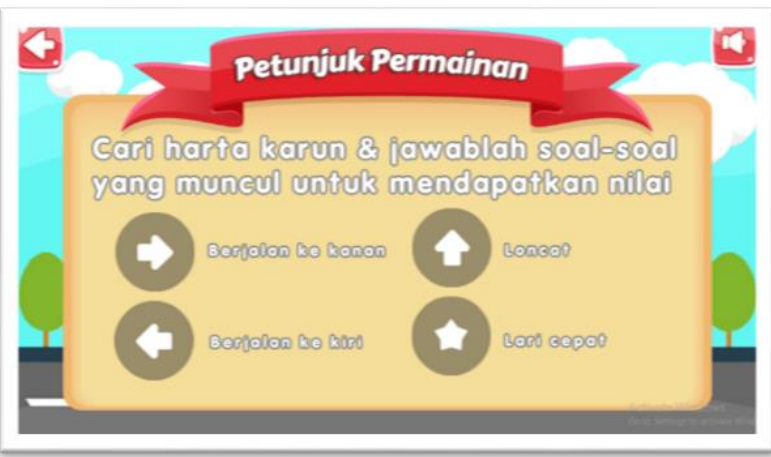

Gambar 8. Tampilan Petunjuk

\section{C) Hasil Pengujian}

Pengujian aplikasi ini menggunakan penguian ISO 9126. Adapun hasil pengujiannya sebagai berikut: 


\section{Hasil Pengujian Usability}

Pengujian aspek usability dilakukan terhadap siswa kelas $\mathrm{X}$ Akuntansi 1 Bandar Lampung. Ada sedikitnya 32 responden (siswa) yang menilai aplikasi game, responden (siswa) mencoba game edukasi akuntansi terlebih dahulu, lalu menilai semua pertanyaan kuesioner yang sudah disediakan. Jumlah pertanyaan dalam kuesioner tersebut yaitu 15 pertanyaan dengan mengguakan skala riket SS, S, N ,TS ,STS.

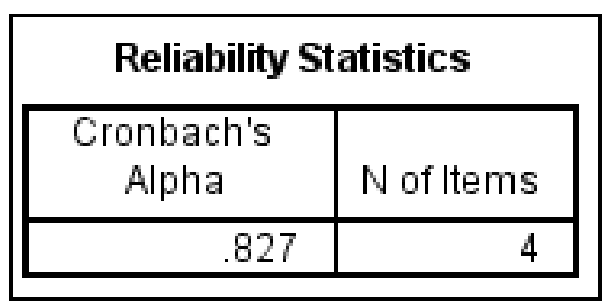

Gambar 9. Hasil Reability Statistich

Kesimpulan hasil uji validitas operability terdapat 4 pertanyaan yang sudah di uji 32 responden (siswa) maka terdapat 4 pertanyaan yang valid karena bobot corrected item-total correlation diatas standar 0.3. Dan reliabilitas statistich di dapat hasil Cronbach's alpha .827 dari 4 pertanyaan yang dimana nilai tersebut di atas nilai bobot reliabilitas statistich 0.6. Maka kesimpulan dari data di atas di simpulkan bahwa pertanyaan tersebut dapat diterima baik dan reliabel.

\section{Reliability Statistics}

\begin{tabular}{|r|r|}
\hline $\begin{array}{c}\text { Cronbach's } \\
\text { Alpha }\end{array}$ & N of ltems \\
\hline .790 & 3 \\
\hline
\end{tabular}

Gambar 10. Hasil Reability Statistich

Kesimpulan hasil uji validitas learnability terdapat 3 pertanyaan yang sudah di uji 32 responden (siswa) maka terdapat 3 pertanyaan yang valid karena bobot corrected item-total correlation diatas standar 0.3. Dan reliabilitas statistich di dapat hasil Cronbach's alpha .790 dari 3 pertanyaan yang dimana nilai tersebut di atas nilai bobot reliabilitas statistich 0.6 . Maka kesimpulan dari data di atas di simpulkan bahwa pertanyaan tersebut dapat diterima baik dan reliabel.

\section{Reliability Statistics}

\begin{tabular}{|r|r|}
\hline $\begin{array}{c}\text { Cronbach's } \\
\text { Alpha }\end{array}$ & N of Items \\
\hline .733 & 2 \\
\hline
\end{tabular}

Gambar 11. Hasil Reability Statistich

Kesimpulan hasil uji validitas understandability terdapat 2 pertanyaan yang sudah di uji 32 responden (siswa) maka terdapat 2 pertanyaan yang valid karena bobot corrected item-total correlation diatas standar 0.3. Dan reliabilitas statistich di dapat hasil Cronbach's alpha .733 dari 2 pertanyaan yang dimana nilai tersebut di atas nilai bobot reliabilitas statistich 0.6 . maka kesimpulan dari data di atas di simpulkan bahwa pertanyaan tersebut dapat diterima baik dan reliabel.

\section{Reliability Statistics}

\begin{tabular}{|r|r|}
\hline $\begin{array}{l}\text { Cronbach's } \\
\text { Alpha }\end{array}$ & N of Items \\
\hline .845 & 6 \\
\hline
\end{tabular}

Gambar 12. Hasil Reability Statistich Attractiveness

Kesimpulan hasil uji validitas attractiveness terdapat 6 pertanyaan yang sudah di uji 32 responden (siswa) maka terdapat 6 pertanyaan yang valid karena bobot corrected item-total correlation diatas standar 0.3. Dan reliabilitas statistich di dapat hasil Cronbach's alpha .845 dari 6 pertanyaan yang dimana nilai tersebut di atas nilai bobot reliabilitas statistich 0.6. maka kesimpulan dari data di atas di simpulkan bahwa pertanyaan tersebut dapat diterima baik dan reliabel.

\section{Hasil Pengujian Functionality}

Pengujian aspek functionality dilakukan terhadap orang yang memiliki keahlian dalam bidang software engineering untuk mengetahui apakah fungsi-fungsi pada game dapat berjalan dengan benar. Jumlah pertanyaan dalam kuesioner tersebut yaitu 24 pertanyaan dengan mengguakan skala riket Sukses dan Gagal. Hasil pengujian functionality dapat dilihat pada gambar 28 berikut ini:

\begin{tabular}{|c|c|c|c|c|c|c|}
\hline \multicolumn{7}{|c|}{ Binomial Test } \\
\hline & & Category & N & $\begin{array}{l}\text { Observed } \\
\text { Prop. }\end{array}$ & TestProp. & Exact Sig. (2-tailed) \\
\hline jWb & $\begin{array}{l}\text { ryan } \\
\text { randy } \\
\text { Total }\end{array}$ & sukses & $\begin{array}{l}24 \\
24\end{array}$ & $\begin{array}{l}1.00 \\
1.00\end{array}$ & .50 & 1.000 \\
\hline
\end{tabular}

Gambar 13. Hasil Output Uji Statistik Non Parametrik Pada gambar 28 diatas menunjukkan exact Sig. (2-tailed) adalah 1 atau probabilitas lebih besar dari 0,05 sehingga diterima bahwa data berdistribusi normal dari 24 pertanyaan memenuhi kriteria normalitas.

\section{Hasil Pengujian Efficiency}

Pengujian aspek efficiency menggunakan Testdroid secara online. Dengan Testdroid dapat diamati penggunaan memory (RAM), dan CPU. Dalam pengujian aspek efficiency ini digunakan device yang sudah disediakan oleh Testdroid yaitu menggunakan device LG Google Nexus 5 6.0.1. Berikut ini hasil pengujian aspek efficiency dengan tools Testdroid:

a. Memory (RAM), dalam pengujian penggunaan memory diukur setiap 2 detik eksekusi pengujian. Grafik penggunaan memory oleh aplikasi dapat dilihat pada gambar 14. 


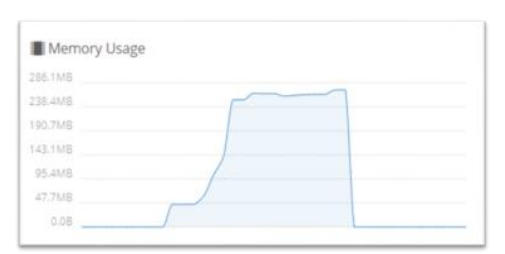

Gambar 14. Penggunaan Memory Aplikasi b. $\quad \mathrm{CPU}$, dalam pengujian penggunaan $\mathrm{CPU}$ diukur setiap 2 detik eksekusi pengujian. Penggunaan CPU diambil dengan menggunakan perintah top shell. Persentase CPU yang ditunjukkan oleh top merupakan ukuran dari seberapa sering proses tunggal dimuat oleh kernel untuk berjalan di CPU, rata-rata selama periode waktu. Grafik penggunaan CPU oleh aplikasi dapat dilihat pada gambar 15 .

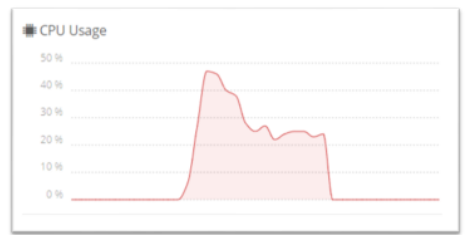

Gambar 15. Penggunaan CPU Aplikasi

\section{Hasil Pengujian Portability}

Hasil dari pengujian portability dapat disimpulkan juga untuk menjalankan aplikasi game edukasi Akuntansi, dibutuhkan smartphone dengan spesifikasi minimum sebagai

berikut:

a. Processor Dual Core atau yang lebih bagus.

b. Memory (RAM) $512 \mathrm{MB}$ atau lebih.

c. Sistem operasi Android 4.1.1 (Jelly Bean) atau lebih baru

\section{Kesimpulan}

\section{a. Kesimpulan}

Berdasarkan hasil penelitian dan pembahasan dari hasil penelitian terhadap Game Edukasi Akuntansi Sebagai Sarana Peningkatan Minat Belajar Siswa, maka dapat disimpulkan sebagai berikut:

1. Telah dibangun sebuah game edukasi akuntansi sebagai sarana peningkatan minat belajar siswa, sebagai media pengenalan materi ayat jurnal penyesuaian pada perusahaan jasa yang menyenangkan dan menarik agar dapat meningkatkan minat siswa untuk memahami materi.

2. Hasil pengujian kualitas aplikasi game edukasi akuntansi dihitung dengn menggunakan SPSS yang meliputi aspek functionality, usability, portability dan efficiency, yaitu sebagai berikut:

a) Hasil pengujian kualitas aspek usability oleh 32 siswa kelas X Akuntansi 1 Bandar Lampung dengan output Cronbach alpha 0,949 yang berarti aspek usability aplikasi ini dapat diterima baik dan reliable.

b) Hasil pengujian kualitas aspek functionality oleh 2 (dua) orang di bidang software engineering menunjukan bahwa aplikasi dapat melakukan $100 \%$ fungsinya dengan benar. c) Hasil pengujian kualitas aspek portability pada beberapa device dengan sistem operasi Android versi, Gingerbread, Jelly Bean, Kitkat, Lollipop, Marshmallow dan Nougat, menunjukkan aplikasi hanya dapat di-install dan dijalankan pada device dengan versi android Jelly Bean ke atas.

d) Hasil pengujian kualitas aspek efficiency dengan Testdroid menunjukkan tidak mengalami kekurangan memory yang menyebabkan terjadinya memory leak dan mengakibatkan aplikasi berhenti, penggunaan CPU maksimum $47 \%$ pada saat awal menjalankan aplikasi, rata-rata penggunaan $\mathrm{CPU}$ berada di angka $20 \%$.

\section{b. Saran}

Berdasarkan kesimpulan dari hasil penelitian yang telah diuraikan, maka saran yang dapat diberikan untuk peneliti selanjutnya terhadap game edukasi akuntansi sebagai sarana peningkatan minat belajar siswa adalah :

1. Aplikasi ini menggunakan construct 2 masih belum sepenuhnya sempurna, karena ada beberapa tempat dimana karakter masih sulit untuk bergerak.

2. Aplikasi ini dapat dikembangkan dengan menambahkan materi akuntansi yang lain pada game edukasi.

3. Menggunakan alternatif game engine lainnya, sehingga besar penggunaan CPU pada awal aplikasi dijalankan dapat minimalkan.

\section{Daftar Pustaka}

A.S, R. \& SHALAHUDDIN, M., 2015. Rekayasa Perangkat Lunak. In: Terstruktur dan Berorientasi Objek. Bandung: Informatika Bandung, pp. 175-208.

ARSYAD, A., 2011. Media Pembelajaran. Rajawali Pers.

ASSAF B, D., 2011. Mobile Aplication Testing (Best Practices to Ensure Quality). Amdocs, 2.

DITTO, R. P. \& MAHENDRA, A. N., 2016. Pengembangan Game Edukasi Berbasis Android Sebagai Media Pembelajaran Akuntansi Pada Materi Jurnal Penyesuaian Perusahaan Jasa. Universitas Negri Yogyakarta, Volume XIV.

DONY, N., 2013. APLIKASI GAME GEOGRAFI BERBASIS MULTIMEDIA INTERAKTIF. Elektronika Fakultas Teknik, Universitas Negri Padang, Volume VI, p. ISSN : 2086 - 4981.

GHOZALI, IMAM. 2013. Aplikasi Analisis Multivariate dengan Program SPSS. Edisi Ketujuh. Semarang : Badan Penerbit Universitas Diponegoro.

HANNY, H. \& RAHMATSYAM, L., 2012. GAME EDUKASI "EVAKUATOR" BERGENRE PUZZLE DENGAN GAMEPLAY BERBASIS KLASIFIKASI SEBAGAI SARANA PENDIDIKAN DALAM MITIGASI 
BENCANA. Universitas Dian Nuswantoro, Semarang, Volume XI.

Hasyim, L. A. P. \& Mulyadi, V., 2015. Kajian Pengenalan Alfabet untuk Anak Usia 3-5 Tahun Dalam Bentuk Board Game. Jurnal RupaRupa, $\operatorname{IV}(2)$, p. 143.

IBM SPSS Statistics 20(www.Downloadha.com)

Jogiyanto. HM, 2010, "Perancangan Sistem Informasi Pengenalan Komputer". Pustaka Pelajar, Yogyakarta.

Mariati, 2016. Pengembangan Media Pembelajaran Multimedia Interaktif Model Games "Gedutan" Dalam Pembelajaran Akuntansi Pada Siswa Kelas X Smk - Bm Se- Kota Medan. Universitas Muhammadiyah Sumatera Utara, Medan.

Mohamad, A. \& al, e., 2015. Perancangan Game Edukasi Platform Belajar Matematika Berbasis Android Menggunakan Construct 2. Kampus UNDIP Tembalang, Volume IV.

Nadya \& Paramitha, M., 2014. PERANCANGAN DESAIN GAME "MONKEYKING JOURNEY TO THE WEST". JURNAL RUPARUPA, III(2).

Nia, A. S. \& Mardono, 2016. PENGEMBANGAN MEDIA PEMBELAJARAN GAME EDUKASI PADA MATA PELAJARAN EKONOMI KELAS $X$ IIS SMA LABORATORIUM UNIVERSITAS NEGERI MALANG. Universitas Negri Malang, Volume IX.

Roedavan, R., 2017. Construct 2 Tutorial Game Engine. Bandung: Informatika.

Romney, M. \& Steinbart, P., 2012. Accounting Information System. United States: Pearson Prentice Hal.

Sucipto, Toto., et al, 2011. Siklus Akuntansi Perusahaan Jasa dan Perusahaan Dagang. Yudhistira. ISBN : 987-979-029-079-8.

Sutabiri, 2012, Konsep Sistem Informasi, Andi Yogyakarta.

Sutopo, A., 2003. Analisis dan Desain Berorientasi Objek. Yogyakarta: J\&J Learning.

Suryono, Bambang (2008) Analisis Regresis Terapan dengan SPSS. Yogyakarta: Graha Ilmu.

Tian, J., SOFTWARE QUALITY ENGINEERING, In V. Moliere, Ed. TESTING QUALITY ASSURANCE, AND QUANTIFLABLE IMPROVEMENT. Canada: Jhon Wiley \& Shons, Inc., Hoboken, New Jersy 2005.

Yudhi, M., 2008. Media Pembelajaran. GP Press. 